
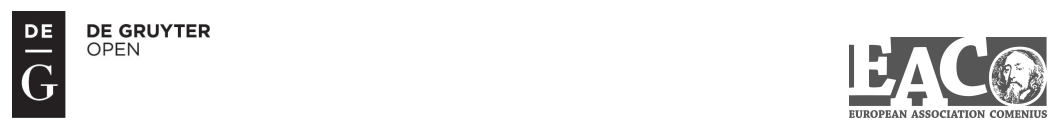

\title{
EXPENDITURES ON COLLECTIVE AND INDIVIDUAL SERVICES: Discussion ON THE Classification OF GOVERnMENT EXPENDITURES WITH REGARD TO THEIR INCLUSION INTO GROWTH MODELS
}

\author{
Zuzana Machová ${ }^{1}$ \& Igor Kotlán ${ }^{2}$
}

\begin{abstract}
The aim of this paper is to examine the effects of government expenditures on long-run economic growth in developed countries using their different breakdown. Empirical analysis is performed for a panel of 34 OECD countries in the period 2000-2012. Above all, the results support the idea that conclusions of previous studies on this topic may be strongly distorted by inappropriate classification of expenditures, typically in the case of expenditures on education and health. These are usually considered productive and thus growth enhancing, but if their part of R\&D expenditures is detached, their effect on growth is in fact negative. In general, it is concluded that government expenditures on individual services have negative effects on growth, while the impact of expenditures on collective services is positive.
\end{abstract}

\section{Keywords}

Government Expenditures, Economic Growth, Collective Services, Individual Services

\section{Introduction}

The recent period has given rise to a body of literature concerning the influence of fiscal policy on economic growth. This development is natural, as the professional economic public tries to answer the research questions that have appeared in connection with economic, financial or debt crises. ${ }^{3}$ Economists analyze either the influence of different types of taxes, or the influence of different types of government expenditure on economic growth,

\footnotetext{
${ }^{1}$ VŠB - Technical University of Ostrava, Faculty of Economics, Sokolská tř. 33, 72100 Ostrava, Czech Republic. E-mail: zuzana.machova@vsb.cz.

${ }^{2}$ VŠB - Technical University of Ostrava, Faculty of Economics, Sokolská tř. 33, 72100 Ostrava, Czech Republic. E-mail: igor.kotlan@vsb.cz.

${ }^{3}$ For more on this topic from several interesting points of view, see e.g. Funta, 2011; Kačaljak, 2011; Endovitskiy and Lomsadze, 2012; Aiginger, Horvath and Mahringer, 2012; Fleichuk and Hnat, 2012; Ziyadin, 2012; Cheng, Choong and Leong, 2012; Caba, 2013; Olteanu, 2013; or Šišková, 2013.
} 
but nowadays the aggregate influence of all the fiscal variables on growth is studied above all. In the analyses, in accordance with contemporary literature, direct and indirect taxes are usually distinguished, as well as productive and unproductive government expenditures. The explanation of the categorization of taxes is that direct taxes have higher distortionary effects on the economy and thus harm economic growth more. In the case of government expenditures, there is an assumption that productive government expenditures are investment expenditures that support economic growth, while unproductive, consumption expenditures do not. However, the conclusions of empirical studies are contradictory. It has been neither significantly confirmed what the effects of separate types of taxes are, nor what the effects of particular types of expenditures are.

While the issues of the influence of taxes on growth were examined in several recent papers (Kotlán and Machová, 2012a, 2013; Machová and Kotlán, 2013a) and are not of interest in this paper, the effects of government expenditures seems a rather unexplored area. Starting from economic theory, there are also doubts about the accuracy of the classification of expenditure into productive and unproductive parts, or rather about the accuracy of the assignment of specific types of expenditures to productive or unproductive parts. There appears to be a question as to whether another classification would be better, with respect to the analysis of government expenditures effects on growth. One possibility is to study the separate effects of expenditures on individual, and on collective services including expenditures on R\&D.

Thus the aim of this paper is to examine the effects of government expenditures on economic growth in developed countries, using their standard breakdown into productive and unproductive parts, along with alternative categorization. Empirical analysis is performed for a panel of 34 OECD countries in the period 2000-2012.

\section{Theoretical and empirical background}

Current growth theory is based on the model of Solow (1956) and its extension towards the endogenization of technological progress (Lucas, 1988; Romer, 1986). In the original Sollow model, fiscal policy could not influence economic growth in a steady-state, i.e. the growth of developed economies. But later work, e.g. Barro and Sala-i-Martin (2004), shows that fiscal policy may affect particular growth variables (physical and human capital accumulation above all), and thus also the growth. According to Barro (1990) or Rebelo (1991), the growth rate of an economy $(\gamma)$ in a steady state is equal to the growth rate of physical capital $(k)$, human capital $(h)$, and the growth rate of consumption $(c)$ of households, and depends on intertemporal elasticity of substitution in consumption $(1 / \theta)$ adjusted to time preference rate $(\rho)$, and net marginal rate of return on capital (both human and physical):

$$
\gamma=\frac{\dot{k}}{k}=\frac{\dot{h}}{h}=\frac{\dot{c}}{c}=\frac{1}{\theta}(r-\rho) .
$$

In the basic model (1), taxes may affect the growth rate through their effect on the net marginal rate of return on capital. The channels are described in Mendoza, Milesi-Ferreti and Asea (1997), or Denaux (2007) in detail. 
According to Barro (1990), government expenditures may be considered an input to private production in the event that they are of investment character (expenditures on infrastructure above all). In that case, government expenditures have a positive effect on economic growth, as they raise the net marginal rate of return on capital. Many empirical studies have been based on Barro's assumption, and this type of government expenditures has become labelled productive (see e.g Kneller, Bleaney and Gemmell, 1999; Gemmell, Kneller and Sanz, 2011; Denaux, 2007). However, the studies differ in what type of real government expenditures they include into the productive part.

For simplicity, Barro (1990) assumes the broad concept of capital that includes both physical and human capital (consistently with Rebelo (1991) and his AK model). With constant returns to scale, the production $(\mathrm{Y})$ function thus shall be as follows:

$$
Y=A K\left(\frac{G}{K}\right)^{\alpha}=K \phi\left(\frac{G}{K}\right),
$$

where $A$ is the technology level, $K$ is capital, $G$ is productive government expenditure, $\alpha$ is technological coefficient, and $\phi$ expresses a positive decreasing marginal product (i.e. $\phi^{\prime}>0$ and $\phi^{\prime \prime}<0$ ). For the purposes of expressing the relationship between government expenditure and economic growth, it is possible to assume the existence of a flat tax rate on income $\tau$, which is used to fund government expenditure: $G=\tau Y=\tau K \phi(G / K)$, in the case of a balanced budget. For simplicity, different rates for different types of taxes are not considered. ${ }^{4}$ The net marginal return on capital is then equal to:

$$
r=(1-\tau) \phi\left(\frac{G}{K}\right)\left(1-\phi^{\prime} \frac{G}{Y}\right)=(1-\tau) \phi\left(\frac{G}{K}\right)(1-\eta),
$$

where $\eta$ is the sensitivity of $Y$ to changes in $G$ for a given $K$, and the growth rate of an economy is modified from the equation (1) to:

$$
\gamma=\frac{1}{\theta}\left[(1-\tau) \phi\left(\frac{G}{K}\right)(1-\eta)-\rho\right]
$$

As already stated, the growth rate of the economy is thus positively affected by productive government expenditure, but the sensitivity of production to changes in government expenditure has, on the other hand, a negative influence on growth.

The most important study by Kneller, Bleaney and Gemmell (1999) uses the standard Classification of the Functions of Government (COFOG), but distinguishes only between a group of productive expenditures (including general public services, defense, educational, health, housing, and transport and communication expenditures), and a group of unproductive expenditures (including social security and welfare expenditures, expenditures

\footnotetext{
4 The influence of different types of taxes is taken into account e.g. in Kotlán and Machová (2013). They show the channels through which the taxes affect the growth variables. They also point out that some economic and legal aspects of labor markets must be considered in the analyses. For these aspects, see e.g. Horvath, 2012; Simonovits, 2012; Serban, 2012; Zvonar, 2012; Samosyonok, 2012; Huber and Bock-Schappelwein, 2013; Simonovits, 2013; Schovánková, 2013; Birčiaková, Stávková and Antošová, 2013; or Nagy and Való, 2013.
} 
on recreation, and on economic services). The authors show that the group of productive expenditures really positively affect growth, while unproductive ones do not.

Among similar studies, Denaux (2007) must also be mentioned. He uses the breakdown of expenditures on government expenditures to physical capital accumulation (approximated by stock of roads per cap.), and expenditures to human capital accumulation (approximated by government spending on schooling). He finds no significant effect of spending on physical capital, but he confirms the positive effect of spending on human capital, i.e. on higher education on economic growth.

However, as already stated within the introduction, the results of empirical analyses are not consistent, especially when a more detailed level of classification of expenditures is used. For example, Drobiszová and Machová (2014) also use the COFOG, but they include all the main types of expenditures into their analysis. They show that only spending on defense, education, health, and general public services have a positive effect on economic growth. Unlike the abovementioned studies, the positive effects of expenditures on infrastructure were not confirmed.

Recent experience from OECD countries shows that public wages, interest payments, subsidies and government consumption are less growth enhancing, while spending on education and health boosts growth (Afonso and Jalles, 2014). It is also interesting to realize the consequences of the fact that Bhattacharya and Mukherjee (2013) confirm that households in the OECD move from non-Ricardian to Ricardian behaviour as government debt reaches high levels and as uncertainty about future taxes increases.

At first glance it may seem that expenditures on, e.g. education and health, i.e. human capital, are provably supporting economic growth, while the effects of expenditures on, e.g. infrastructure are questionable. But it is very important to realize that, according to the methodology of COFOG 98, all of the main categories of government expenditures also include corresponding expenditures on $\mathrm{R} \& \mathrm{D}$. This may significantly distort the analyses. One of the ways to avoid this problem is to distinguish between expenditures on collective services, and individual services, which should be closer to Barro's approach above, assuming that expenditures on collective services have positive effects on growth, while expenditures on individual services do not. The classification and further explanation are described in following part.

\section{Methodology and data}

According to the OECD and Eurostat (2012), individual services are the services that general government provides to specific identifiable households. That is, services such as health and education, which are consumed by households individually. Collective services are those that the general government provides simultaneously to all members of the community. That is, services such as defense and public order and safety, which are consumed by households collectively. Because they are considered as part of gross fixed capital formation ${ }^{5}$, the R\&D for individual services are also included, which is the most important point of the classification. Collective services also include the overall policy-making,

\footnotetext{
${ }^{5}$ According to the SNA 2008, and ESA 2010.
} 
planning, regulatory, budgetary, coordinating and monitoring responsibilities of ministries overseeing individual services. These activities, unlike the services to which they relate, cannot be identified with specific individual households and are considered to benefit households collectively. Based on the COFOG 98, individual services (IS) include expenditures on:

- Health (category 7),

- Recreation, culture and religion (8),

- Education (9),

- Social protection (10),

except for categories including $\mathrm{R} \& \mathrm{D}(7.5,8.4,8.5,9.7,10.8)$, and n.e.c. categories (7.6, 8.6, 9.8, 10.9).

The excepted categories as well as categories:

- General public services (1),

- Defense (2),

- Public order and safety (3),

- Economic affairs (4),

- Environment protection (5)

- Housing and community amenities (6), make up the group of collective services (CS).

From a methodological point of view, the analysis was based on a dynamic panel model which used data for 34 OECD countries in the period 2000-2012. Potential output per worker in PPP $(Y)$ was dependent variable. Independent variables included control growth variables, i.e. gross fixed capital formation as a percentage of GDP $(K)$, and total factor productivity expressed as GDP per worked hour $(L)$.

The second group of independent variables was formed by fiscal variables. The model included both the revenue and expenditure side of the budget; fiscal balance was omitted to avoid perfect collinearity of the variables. Regression coefficients of the fiscal variables may thus be interpreted as a change of the potential output in the case that the corresponding variable as well as the fiscal balance in opposite direction is changed by unit, ceteris paribus. Fiscal variables included direct taxes $(D T)$, indirect taxes $(I T)$, both expressed as corresponding tax quota, i.e. tax revenue-to-GDP ratio $^{7}$, and finally government expenditures. At first, productive $(P E)$ and unproductive $(U E)$ expenditure in accordance with Kneller, Bleaney and Gemmell (1999) were included, and secondly expenditures on individual services $(I S)$ and collective services $(C S)$, all of them expressed as a percentage of GDP.

\footnotetext{
${ }^{6}$ The extend of all the expenditure types is involved by national and international laws. However, in the case of environmental protection, the impact of laws is very strong (for more on the legal aspects, see e.g. Černič, 2012; Bogataj, 2012; Škrk, 2012; or Gaberščik, 2012).

${ }^{7}$ Alternative indices could be also used, e.g. the World Tax Index (Kotlán and Machová, 2012b; Machová and Kotlán, 2013b).
} 
The data was gained from OECD iLibrary, specifically the OECD Tax Database, and the database of national accounts.

As the estimation technique, a generalized method of moments (GMM) was used, which included the method of instrumental variables. This method uses the Arellano-Bond estimator (Arellano, Bond, 1991), and the transformation method of first difference of each variable in the regression, which prevents potential problems with the stacionarity of the time series. Using a robust estimator in calculating the covariance matrices (White Period method) ensured that the estimation results of standard deviations of parameters and hypothesis tests were correct with regard to a possible occurrence of autocorrelation and heteroscedasticity. This estimation type ensures that the appropriate transformation process and using appropriate instruments eliminates the risk of endogeneity of the lagged values of the dependent variable and the independent variables with a random component. In the analyses below, the lagged values of the dependent variable were used as the instruments, starting from a lag of two. A Sargan test (see the J-statistics in the tables below) confirmed the validity of the instruments in both estimated models.

Assuming a lagged effect of fiscal policy on economic growth, a lag of one period designed with $(-1)$ was used in the case of fiscal variables. For better interpretation of the regression coefficients, all the variables were used in logarithmic form.

\section{Empirical analysis and results}

This part of the paper is devoted to the impact of government expenditures on longrun economic growth, expressed by the estimates of the potential output for each OECD country. Table (1) shows the results of the estimation of the model including productive and unproductive government spending according to Kneller, Bleaney and Gemmell (1999). Table (2) shows the results from the model where government expenditures were divided on expenditures on collective services, and on individual services.

Table 1: Effects of productive and unproductive expenditures on growth

\begin{tabular}{|l|rcc|}
\hline Variable & Coefficient & Std. Error & t-Statistic \\
\hline$G D P(-1)$ & 0.895393 & 0.001923 & $465.5316^{* * *}$ \\
$K$ & 0.009173 & 0.000908 & $10.10532^{* * *}$ \\
$L$ & 0.032129 & 0.001090 & $29.46243^{* * *}$ \\
$D T(-1)$ & -0.030982 & 0.001878 & $-16.49942^{* * *}$ \\
$I T(-1)$ & -0.017438 & 0.001042 & $-16.73826^{* * *}$ \\
$P E(-1)$ & -0.000802 & 0.000625 & -1.284099 \\
$U E(-1)$ & -0.014670 & 0.000574 & $-25.54178^{* * *}$ \\
\hline Instrument rank & 35 & & \\
J-statistic & 34.20847 & & \\
\hline
\end{tabular}

Notes: all variables are expressed in logarithmic form; $t$-statistics are adjusted for heteroskedasticity and autocorrelation; standard deviations are calculated using robust estimates; *, **, *** indicate significance levels of 10\%, 5\%, and 1\%, respectively.

Source: own calculations 
In both models, a statistically significant positive effect of control growth variables was confirmed, with total factor productivity having a quantitatively stronger impact on longrun growth, which corresponds to economic theory for developed countries. Also, in both models, a statistically significant negative effect of taxes was confirmed, and the negative effect of direct taxes is quantitatively higher than the effect of indirect taxes. This supports the conclusions of most empirical studies on this topic, e.g. Kotlán and Machová (2012a, 2013), or Machová and Kotlán (2013a).

Table 2: Effects of expenditures on collective and individual services on growth

\begin{tabular}{|l|rcr|}
\hline Variable & Coefficient & Std. Error & t-Statistic \\
\hline$G D P(-1)$ & 0.897221 & 0.003321 & $270.1565^{* * *}$ \\
$K$ & 0.013152 & 0.001260 & $10.44037^{* * *}$ \\
$L$ & 0.036305 & 0.001601 & $22.67938^{* * *}$ \\
$D T(-1)$ & -0.026248 & 0.002000 & $-13.12116^{* * *}$ \\
$I T(-1)$ & -0.020497 & 0.000642 & $-31.93569^{* * *}$ \\
$C S(-1)$ & 0.005908 & 0.001002 & $5.897708^{* * *}$ \\
$I S(-1)$ & -0.015145 & 0.000911 & $-16.63241^{* * *}$ \\
\hline Instrument rank & 35 & & \\
J-statistic & 35.69204 & & \\
\hline
\end{tabular}

Notes: all variables are expressed in logarithmic form; $t$-statistics are adjusted for heteroskedasticity and autocorrelation; standard deviations are calculated using robust estimates; *, **, *** indicate significance levels of 10\%, 5\%, and 1\%, respectively.

Source: own calculations

With regard to the aim of the paper, the results concerning government expenditures are, nevertheless, the most important. Table (1) shows, that the influence of both productive and unproductive expenditures, classified according to Kneller, Bleaney and Gemmell (1999), on economic growth is negative, although the effect of productive expenditures is quantitatively lower.

On the other hand, if the expenditures are examined in categorization on expenditures on collective and individual services (table 2), it is shown that the impact of expenditures on collective services is positive, while the effect of expenditures on individual services on growth is negative and quantitatively corresponds to the effect of unproductive expenditures.

\section{Conclusion}

The topic of fiscal policy and its impact on economic growth is very current, especially with regard to research questions that have arisen with the recent economic, financial and debt crises. Fiscal consolidation is inevitable in many countries, and their fiscal authorities are forced to make budget cuts, which is in direct conflict with the standard Keynesian approach. Furthermore, many empirical papers have confirmed the negative effects of most types of taxes on economic growth. Improving fiscal balance by raising taxes could thus be counterproductive. On the other hand, there also exist theoretical as well as empirical studies showing that certain types of government expenditures may 
have significant positive effects on economic growth. Restructuring the expenditures side of a budget could thus improve the performance of the economy without any negative effects on fiscal balance.

Most of the previous studies distinguish between the effect of so-called productive and unproductive government spending. However, unproductive expenditures also include expenditures on R\&D in those studies, as well as expenditures on education and health which are of an individual character. These methodological discrepancies may be easily avoided using a classification distinguishing between expenditures on collective services, and expenditures on individual services, which is also in accordance with new national accounting methodology SNA 2008 and ESA 2010.

This approach was also used in this paper, where a dynamic panel model for 34 OECD countries in the period 2000-2012 was estimated, using a GMM and instrumental variables method. Two models were estimated - the first included government expenditures classified as productive and unproductive in accordance with the literature, while the second included expenditures on collective, and on individual services. In the first model, both types of government expenditures have a negative effect on growth, which only supports the inconsistency of the results in the case of the breakdown of expenditures used in the analysis. On the other hand, in the second model, it is shown that, in accordance with the assumptions, expenditures on collective services, including all the expenditures on R\&D, positively affect long-run economic growth, while the expenditures on individual services, including individual expenditures on education and health, affect growth negatively. The results support the idea that the conclusions of previous studies on this topic may be strongly distorted by the inappropriate classification of expenditures, typically in the case of expenditures on education and health. These are usually considered productive, but if their part of R\&D expenditures is detached, their effect on growth is in fact negative.

\section{References}

Afonso, A., Jalles, J. T. (2014). Fiscal Composition and Long-term Growth. Applied Economics, 46(3), 349-358.

Aiginger, K., Horvath, T., Mahringer, H. (2012). Why labor market response differed in the great recession: The impact of institutions and policy. DANUBE: Law and Economics Review, 3(3), 1-19.

Arellano, M., Bond, S. (1991). Some Tests of Specification for Panel Data: Monte Carlo Evidence and an Application to Employment Equations. Review of Economic Studies, 58, 277-297.

Barro, R. J. (1990). Government Spending in a Simple Model of Endogenous Growth. The Journal of Political Economy, 98(5), 103-125.

Barro, R. J., Sala-i-Martin, X. (2004). Economic Growth. $2^{\text {nd }}$ ed. MIT Press, 2004. Bhattacharya, R., Mukherjee, S. (2013). Non-Kenynesian Effects of Fiscal Policy in OECD Economies: An Empirical Study. Applied Economics, 45(29), 4122-4136.

Birčiaková, N., Stávková, J., Antošová, V. (2013). Income (in)justice in the Czech Republic. C, 4(3), 185-199. 
Bogataj, L. K. (2012). International environmental law and acceleration of global change. DANUBE: Law and Economics Review, 3(3), 43-53.

Caba, S. (2013). Economic crisis and globalization index dynamics. Actual Problems of Economics, (1), 527-537.

Černič, J. L. (2012). Corporate obligations under the right to a healthy living environment. DANUBE: Law and Economics Review, 3(3), 21-41.

Denaux, Z. S. (2007). Endogenous growth, taxes and government spending: Theory and evidence. Review of Development Economics, 11(1), 124-138.

Drobiszová, A., Machová, Z. (2014). The appropriate mix of government spending and taxation: How to promote economic growth? In Vision 2020: Sustainable Growth, Economic Development, and Global Competitiveness - Proceedings of the 23rd International Business Information Management Association Conference, IBIMA 2014, (1), 1882-1890. Endovitskiy, D. A., Lomsadze, D. G. (2012). World economic crisis: Analyzing the reasons. Actual Problems of Economics, 138(12), 347-352.

Fleichuk, M. I., Hnat, N. A. (2012). Debt crisis of European countries and its consequences for world economy. Actual Problems of Economics, 131(5), 57-67.

Funta, R. (2011). Economic law and economic crisis. Where do we go from here? Economic, legal and political dimension. DANUBE: Law and Economics Review, 2(1), 65-71.

Gaberščik, A. (2012). The laws of nature also apply to human society. DANUBE: Law and Economics Review, 3(4), 47-53.

Gemmell, N., Kneller, R., Sanz, I. (2011). The Timing and Persistence of Fiscal Policy Impacts on Growth: Evidence from OECD Countries. Economic Journal, 121(550), F33F58.

Horvath, T. (2012). Immigration and the distribution ofwages in Austria. DANUBE: Law and Economics Review, 3(3), 55-69.

Huber, P., Bock-Schappelwein, J. (2013). The impact of migration policy on migrants' education structure: Evidence from austrian policy reform. DANUBE: Law and Economics Review, 4(1), 1-21.

Cheng, M.-Y., Choong, C.-K., Leong, M.-Y. (2012). Economic crises: Nature, consequences and challenges. Actual Problems of Economics, 133(7), 528-537.

Kačaljak, M. (2011). The debt crisis and the means of enforcing the budgetary discipline of eu member states. DANUBE: Law and Economics Review, 2(4), 63-79.

Kneller, R., Bleaney, M., Gemmell, N. (1999). Fiscal Policy and Growth: Evidence from OECD Countries. Journal of Public Economics, 74, 171-190.

Kotlán, I., Machová, Z. (2012a). The Influence of Corporate Taxation on Economic Growth: The Failure of Tax Quota? Politická ekonomie, 60(5), 743-763.

Kotlán, I., Machová, Z. (2012b). World tax index: Methodology and data. DANUBE: Law and Economics Review, 3(2), 19-33.

Kotlán, I., Machová, Z. (2013). The Impact of the Tax Burden on the Living Standard in OECD Countries. Ekonomický časopis, 61(9), 951-962.

Lucas, R. E. (1988). On the Mechanics of Economic Development. Journal of Monetary Economics, 22, 3-39. 
Machová, Z., Kotlán, I. (2013a). Interaction of Taxation, Government Expenditure and Economic Growth: Panel VAR Model for OECD Countries. Politická ekonomie, 61(5), 623-638.

Machová, Z., Kotlán, I. (2013b). World Tax Index: New methodology for OECD countries, 2000-2012. DANUBE: Law and Economics Review, 4(2), 165-179.

Mendoza, E. G., Milesi-Ferretti, G. M., Asea, P. (1997). On the Ineffectiveness of Tax Policy in Altering Long-Run Growth?: Harberger's Superneutrality Conjecture. Journal of Public Economics, 66, 99-126.

Nagy, Z.I., Való, V. (2013). The lawful execution of employer rights is an important subsystem of corporate governance (a labour case study). DANUBE: Law and Economics Review, 4(3), 201-217.

OECD and Eurostat (2012). Eurostat-OECD Methodological Manual on Purchasing Power Parities (2012 Edition). OECD Publishing.

Olteanu, D. C. (2013). Overlending and financial instability in Eastern Europe during the crisis. Actual Problems of Economics, 142(4), 429-441.

Rebelo, S. (1991). Long-Run Policy Analysis and Long-Run Growth. Journal of Political Economy, 99(3), 500-521.

Romer, P. M. (1986). Increasing Returns and Long-Run Growth. Journal of Political Economy, 94(5), 1002-37.

Samosyonok, L. M. (2012). Dynamics of population income and employment in countrymembers of regional integration blocs. Actual Problems of Economics, 136(10), 15-20.

Serban, A. C. (2012). Education and changing labour content-implications on employment. Actual Problems of Economics, 136(10), 536-543.

Schovánková, S. (2013). Determinants of the spatial distribution of foreign employees on different skill job positions: The case of the Czech republic. DANUBE: Law and Economics Review, 4(2), 115-139.

Simonovits, A. (2012). Pension reforms in an aging society: A fully displayed cohort model. DANUBE: Law and Economics Review, 3(4), 1-30.

Simonovits, A. (2013). Does higher tax morale imply higher optimal labor income tax rate? DANUBE: Law and Economics Review, 4(2), 97-114.

Solow, R. (1956). A Contribution to the Theory of Economic Growth. The Quarterly Journal of Economics, 70(1), 65-94.

Šišková, N. (2013). The impact of the Eurozone's crisis on the Institutional Framework and National Law of Member States - Some considerations. DANUBE: Law and Economics Review, 4(4), 293-300.

Škrk, M. (2012). Case law of the constitutional court of slovenia and the protection of the environment. DANUBE: Law and Economics Review, 3(4), 31-45.

Ziyadin, S. (2012). Effect of the world global economic crisis on the condition of banking systems. Actual Problems of Economics, 134(8), 419-429.

Zvonar, Y.P. (2012). Self-employment as a domain for realization of social \& labour potential of population. Actual Problems of Economics, 131(5), 219-227. 